\title{
Analysis of Sustainability Reports and Quality of Information Disclosed of Top Brazilian Companies
}

\author{
Hong Yuh Ching ${ }^{1}$, Fábio Gerab ${ }^{2} \&$ Thiago Toste $^{1}$ \\ ${ }^{1}$ Business Department, Centro Universitário da FEI, Brazil \\ ${ }^{2}$ Mathematics Department, Centro Universitário da FEI, Brazil \\ Correspondence: Hong Yuh Ching, Business Department, Centro Universitário da FEI, Av. Humberto de Alencar \\ Castelo Branco, 3972, São Bernardo do Campo, Brazil. Tel: 55-11-4353-2900. E-mail: hongching@fei.edu.br
}

Received: June 28, 2013

Accepted: August 6, 2013

Online Published: September 23, 2013

doi:10.5539/ibr.v6n10p62

URL: http://dx.doi.org/10.5539/ibr.v6n10p62

\begin{abstract}
The objective of this research is to examine the quality of information disclosed from a sample of Brazilian listed companies, using a multidimensional construct based on economic, environmental and social dimensions of sustainability. The research design combines both quantitative and qualitative methods. The qualitative approach is used in the content analysis procedure and the quantitative is employed for statistical analysis. The target population consists of top 36 sustainable companies (ISE) and 24 with corporate governance practices (NM) in 2011. We find that $37 \%$ of the companies achieved score above $0.5 ; 30 \%$ between 0.26 and 0.5 and $33 \%$ scored below 0.25 , being score zero the worst and one the best score. The best company scored 0.896 and the worst of the 60 companies scored 0.0167 . Overall our statistical results confirm that ISE companies tend to disclose more information and in a more adequate way than NM, and in general, the companies are reporting the content in all the three dimensions with same quality level. Furthermore, companies from Infrastructure sector present better quality content reported when compared to Service companies. We conclude that a good sustainability report is directly related to the good content in all the tree dimensions, regardless the economic sector and these reports still have a big room for improvement, which echoes within the literature analyzed. Companies need to disclose their information in a more integrated way, addressing sustainability issues under the scope of business strategy.
\end{abstract}

Keywords: sustainability reports, triple bottom line, economic dimension, environmental dimension, social dimension

\section{Introduction}

Sustainability is turning into a core business strategy over time, representing a common trend for every big company. Companies are starting to view the sustainable side of their activities as an important performance assessment. Sustainability has been introduced as a new reporting subject for the companies worldwide in the last few years additionally to financial information. According to KPMG (2011a), 95\% of the 250 largest companies around the world have already published reports on the subject, compared to only $45 \%$ in 2002 . It is clear that the so-called sustainability reports turned into common practice and an essential document for every company that is looking for a sustainable image.

As transparency with the specific requirement of publishing sustainability reports is now essential to satisfy and reassure customers and stakeholders expectations (Isarksson \& Staimle, 2009), reporting guidelines for sustainability issues became necessary. However, there has been no real progress towards an official standard of reporting as there is for financial reports (Economist Intelligence Unit (EIU), 2008), despite the rapid increase of the sustainability reports being published as commented above.

The effort to develop indicators that measure sustainability was assessed by some organizations such as International Network for Environmental Management (INEM, 2001). But, over time, the one that emerged as the dominant framework is the Global Reporting Initiative (GRI). The GRI guidelines are being used by most companies around the world (Davys \& Searcy, 2010).

A standard reporting framework makes it easier to assess and compare the performance of different companies, eliminating the risk of uncertainty in measuring different sorts of information (Coalition for Environmentally Responsible Economy (CERES), 2010). Hedberg and Malmborg (2003) conducted a survey among the 
managers of ten Swedish companies, asking them why the GRI guidelines were their choice when elaborating their sustainability reports. Their results showed that the GRI framework gives a credibility aspect to the reports given the fact these guidelines are a globally accepted framework.

Investors are looking for companies that integrate sustainability in their core business practices and view the subject as an essential long-term performance factor (KPMG, 2011b). Value creation refers both to achieving sufficient profit and to satisfying the requests of a diverse group of stakeholders (Hart \& Milstein, 2004). The use of a standard framework for reporting is essentially important for investors. As they get to analyze the reports and compare companies.

Investors are also paying attention to the stock price performance of sustainable companies. Studies linking financial performance and/or performance indicators with sustainable practices or corporate social responsibility practices have been conducted by some authors (Ameer \& Othman, 2012; López, Garcia, \& Rodriguez, 2007). The Dow Jones Sustainability Index (DJSI) was the pioneer in gathering sustainable companies into a unified index, but other stock exchanges, such as Financial Times (in UK) and BM\&F Bovespa (in Brazil), have already separate price indexes. From such indexes, investors and stakeholders should expect companies with deeper sustainability concerns and business practices related. Many of these companies make use of sustainability reports as a tool to measure their own performance on the subject (Caron \& Turcotte, 2009).

The objective of this research is to examine the quality of information disclosed from a sample of top Brazilian listed corporations, using a multidimensional construct based on economic, environmental and social dimensions of sustainability. Similar approach of using these three constructs was adopted by Lopez et al. (2007), Ameer \& Othman (2012), Okoye, Egbunile and Meduoye (2013). The first two papers examined the relationship between sustainability and corporate performance, while the latter studied how the disclosure of these dimensions of sustainability would help resolving issues of stakeholder management. We worked with a sample of 36 firms from the ISE (Índice de Sustentabilidad Empresarial) Index and compared them with the 24 firms from the NM (Novo Mercado) Index for 2011. Information was drawn from a content analysis of their sustainability reports and compared to the information found in the literature. We test hypotheses relating to whether significant differences exist in the information disclosed of companies included in ISE and those in NM (hereby identified to as the control sample). They are:

H1 - Information disclosed of the economic dimension in 2011 of ISE companies is better than in the control companies.

H2 - Information disclosed of the environmental dimension in 2011 of ISE companies is better than in the control companies.

H3 - Information disclosed of the social dimension in 2011 of ISE companies is better than in the control companies.

H4 - There is no difference in the information disclosed of the economic, environmental and social dimensions in 2011 across the four economic sectors.

The assumption behind the first three hypotheses lies on the fact that companies with good sustainability practices (ISE) will pay more attention in all the three dimensions than companies with superior corporate governance practices (control companies). Regarding the $4^{\text {th }}$ hypothesis, we see no reason for the opposite.

The remainder of the paper is organized into four other main sections. The next section is the literature review on other studies regarding sustainability and sustainability reports. Methodology and data collection are presented, providing the context necessary for the following section, which presents the discussion of the results and compare them with the ones found in the literature. Finally, the paper finishes with a brief conclusion that summarizes the objectives and findings of this study.

\section{Literature Review}

The key sustainability drivers highlighted by CERES (2010) are the globalization process, climate changes and the importance of a clear communication with stakeholders, due to how fast any information can be spread around the news nowadays. For Hart and Milstein (2004) the drivers are the never ending industrialization process, the advent of new technologies, the population growth and the proliferation of stakeholders among civil society. KPMG (2011b) underlined that, in the not-too-distant-future, it will be those companies that understand and respond to the issue of sustainability, by making changes to their business models and taking a commercial approach to investing in sustainability programs, that will achieve real and lasting benefits over the long-run.

There is a widely recognized need for individuals, organizations and societies to find tools for assessing the 
extent to which current activities are unsustainable (Singh, Murty, Gupta, \& Dikshit, 2009). The sustainability report is one of these tools (Caron \& Turcotte, 2009). This trend has been analyzed under the scope of three theories, the Legitimacy theory, the Stakeholder theory and the Agency theory.

The Legitimacy theory states that, in order to maintain its business activities, companies need to behave as to what is expected from society (O'Donovan, 2002). The need to legitimate its actions drives companies into making sustainability reports, as the information disclosed in these documents is important to change society's perception towards the company (Deegan, 2002). Cho and Patten (2007) also support the argument that companies use disclosure as a legitimizing tool.

The stakeholder theory presumes that the values of the companies are an important factor as how they do business. So they need to explicitly alert its stakeholders of those values in order to build a meaningful relationship between them (Freeman, Wicks, \& Parman, 2004). Under that scope, Gray, Kouhy and Lavers (1996) say that companies use the sustainability report to shape stakeholders opinions in a positive way, opening doors for them to keep conducting their business activities. Konar and Cohen (2001) state that major companies tend to voluntarily comply with environmental regulations and externally portray an image of being environmentally concerned, being rewarded in the marketplace for taking these actions. According to Aktas, Kayalidere and Kargin (2013), reporting sustainability is a key process to inform stakeholders whether the firm is achieving sustainable growth and value for their interest.

Ross (1973) advocates that the agency theory resides on the situation where there are two forces and one of them (agent) acts in behalf of the other (principal), which may result in interest conflicts. Ness and Mirza (1991) said that a great disclosure level of environmental information is a way to increase company's growth perspective, which they relate to congruence between the principal and the agent's aspirations. Lo and Sheu (2007) state that corporate sustainability increases market value on the long run, which means that the efforts of taking sustainability into the company strategy seem valuable.

Regardless what drives companies to produce sustainability reports and the fact that they are not a mandatory report in most countries, these documents are being integrated in the culture of big companies over time (Sridhar, 2012). The time and effort that companies are putting to produce them lead to a great number of studies in and out of the academic field. Some of these studies analyzed the information disclosed by companies in their reports, approaching the subject in similar ways as we do in this paper.

Perez and Sanchez (2009) addressed the evolution of sustainability reports of four mining companies, from 2001-2006, identifying which Triple Bottom Line (TBL) aspect was receiving more attention. They found that the social aspect was the most reported by those companies, followed by the environmental and economic aspects. The reports began to be more clear and profound over the years. On the other hand, Roca and Searcy (2012) concluded that all TBL aspects were disclosed with relatively equal frequency, when analyzing the 2008 reports from 94 different companies.

Quick (2008) measured the quality of the information disclosed by German companies from 2000-2003. He gave different scores to the information in the reports, depending on whether or not the information was explicitly disclosed. His results showed an average level of quality of $40.6 \%$, which he considered unsatisfactory. $\mathrm{He}$ also identified a slight relation between a good quality level of disclosure and the presence of the company in a sustainability price index. A similar result was found by Rover et al. (2008) that identified that the level of disclosure of analyzed companies was related to their presence on ISE price index.

Schönbohm \& Hofmann (2012) assessed the question whether sustainability is an integrated part of the management system of companies listed in the TecDAX index (which comprises the 30 largest German companies from the technology sector). They analyzed 20 reports of 2010 and 18 of 2009. The authors then used a rating system to evaluate the information available and came to the conclusion that most of the companies did not disclosure meaningful, comparable and transparent reports. They raise the suspicion of "green washing" in some of the reports.

Dias (2009) analyzed the level of disclosure of 21 Portuguese companies from three different sectors. The average level of disclosure identified was less than $50 \%$ on the industrial and services sectors, giving that the financial sector achieved only 56\%. Carvalho and Siqueira (2007), while analyzing eight Latin American companies, also identified low levels of disclosure of around $11 \%$ for the economic aspect, $31 \%$ for the environmental aspect and $8 \%$ for the social aspect.

Hubbard (2011) analyzed the differences in reporting between the different sectors of the 30 biggest companies around the world in 2007 as well as verified whether or not the information reported was useful to compare each 
company's performance. He found out that companies generally reported the economic information related only to the current fiscal year, which made impossible to measure the progress of the company. The environmental aspect received great attention, but Hubbard stated that little could be useful from the information disclosed on that aspect as well as on the social aspect.

The common findings between these studies are clearly the low quality of the information disclosed in sustainability reports and the lacking comparability between them. Also, the TBL aspect highlighted in each report is dependent of the economic sector the company represents.

\section{Methodology and Data Collection}

Our research design combines both quantitative and qualitative methods. The qualitative approach is used in the content analysis procedure and the quantitative is employed for statistical analysis. The following sections explain the characteristics of the target population, sources of data, content analysis procedure and appropriate statistical techniques used in our findings and also used for testing the hypotheses.

The companies were chosen due to the nature of the stock exchange indexes: ISE represents a group of companies with good sustainability practices; Novo Mercado (NM) represents a group of companies with the highest level of corporate governance practices. They are part of BM\&F Bovespa (Brazilian Stock Exchange) indexes. ISE index group gathers 51 shares of 38 companies and represent 18 economic sectors. They add up to $\mathrm{R} \$ 961$ billion in market value (equivalent roughly to US\$ 480 billion), equivalent to $43.72 \%$ of total value of companies traded at BM\&F Bovespa (as of 11/23/2011).

We worked with 2011 reports from 60 companies, 36 from ISE (out of 38) and 24 from NM (out of 126), which represent $100 \%$ of the companies that had reported socio environmental information in the form of annual report, corporate social responsibility report or sustainability report. The companies that were left out of the sample did not disclose any report with information related to sustainability. These reports were downloaded from the companies' websites.

The 60 companies were divided into four economic sectors-Financial, Infrastructure, Industrial and Services, derived from the classifications used by BM\&F Bovespa (see table 1).

Table 1. Reports divided by index and economic sector

\begin{tabular}{llll}
\hline & ISE & Novo Mercado & Total \\
\hline Financial & 8 & 1 & 9 \\
Infrastructure & 15 & 1 & 16 \\
Industrial & 10 & 8 & 18 \\
Services & 3 & 14 & 17 \\
Total & 36 & 24 & 60 \\
\hline
\end{tabular}

\subsection{Content Analysis}

The qualitative method chosen to conduct our study was content analysis. It consists in collecting and classifying quantitative and qualitative data into pre-defined aspects in order to find patterns between the information selected (Guthrie \& Abeysereka, 2006).

One of the keys for a successful strategic management is the availability of sustainability accounting tools capable of monitoring and tracking the overall corporate performance from a qualitative and quantitative viewpoint (Perrini \& Tencati, 2006). Despite there are various international efforts to measure sustainability, few of them have an approach taking into account environmental, economic and social aspects (Singh et al., 2009), as it is the case of Global Reporting Initiative (GRI). The GRI is an international organization that composes guidelines for the elaboration of sustainability reports, in which 79 different information/indicators ( 9 from economic, 30 from environmental and 40 from social) related to the sustainability dimensions are evaluated. These data are related to the latest version of the guidelines, G3.1.

We have used GRI pre-defined aspects to classify the information found in the reports, as it is an established framework, with more than $80 \%$ of our sample utilizing the GRI guidelines to write their reports. The framework proposed by GRI consists in the TBL (economic, social and environmental dimensions) divided in aspects and the indicators under the aspects. For example, the EC3 indicator is under the aspect Economic Performance, 
which is under the Economic dimension. To analyze the information disclosed, each indicator has a description stating what kind of information they represent. The EC3 indicator represents "coverage of the organization's defined benefit plan obligations". This description can be used even when not attached to its indicator, which makes it a valid framework to analyze reports, even those that do not use the GRI guidelines. There are 79 indicators therefore, that is the number of topics (information) we looked for in each sustainability report analyzed.

Each topic/information was assigned a score from 0 to 1 using the wording of the sustainability report in the information is not in a systematic and coherent form, we scored it 0.25 . For instance, TIM reported only their Profit \& Loss Statement and tax exemptions granted by the government, with no additional text explaining what those numbers were or meant and how the company approaches the initiatives that lead to the tax exemptions. How all the money mentioned was distributed was not mentioned either. When the information is presented in a systematic and coherent form, but still lacks some content, the score was 0.5 . It can be in the form of statistics and data. Amil, for example, disclosed all the benefits given to their employees, their P\&L Statement and discriminated some of their expenses (but nothing related to value distribution) and reported how conducted its business that year. However, it was not clear how the company will deal this subject in the following years or what policies they have regarding value distribution. When the information does not suffer from any misunderstanding in disclosure and interpretation, but there is little to no evidence that it affects the way the company conduct its business, we gave it a score of 0.75 . When reporting information on Direct Economic Value Generated and Distributed, under the scope of the Economic aspect. Embraer reported every analysis regarding financial performance, stating their policies on value distribution and generation. However, none of the information disclosed linked those policies to the company business strategy. Finally, when the information is presented in its best form and is clearly driving the way the company conducts its business and acts in order to achieve a sustainable development, we scored it 1.This score might be in the form of financial commitment and initiatives such as that provided by Copasa. On the same subject as above, it reported every analysis they had regarding their financial performance. It also included the amount of money destined to the social and environmental initiatives the company conducts and how this money is distributed between the company's employees. Also, they added a small description to the section, stating the importance of those initiatives.

This score approach is akin to United Nations Environment Programme (UNEP )(2002 and 2006) which uses 0-4 scores, where " 0 means no relevant coverage, or nothing sufficiently significant to suggest that the company is taking this issue seriously" and "4 means the reporting is serious, systematic, and extensive and it is clear how reporting is linked to general business decision making and core processes." Morhardt, Baird and Freeman (2002) state that the incorporation of a score system is a great way to identify how deeply a topic was disclosed. However, in allocating the number of points to each criterion, subjective decisions are unavoidable (Quick, 2008). Rating systems are subject to subjectivity despite the relative objectivity of the methods employed in assessing the sustainability (Singh et al., 2009). However, in order to mitigate potential bias in this study, the reports were scored, following the criteria described, by two raters. Subsequently, the discrepancies were analyzed together in order to standardize the analysis. This method provided robustness to our criteria and classification.

\subsection{Methodology to Calculate the Scores and Use of Statistical Techniques}

We created 4 levels in our methodology to calculate the scores. The bottom level, with the 79 information/indicators. We calculated scores (from 0 to 1 ) for each information of the 60 companies individually, based on content analysis. These 79 information/topics were aggregated, in a upper level, by aspect (as defined by the GRI guidelines) and the scores, in each aspect, were calculated using arithmetic mean of their respective indicators. Moving up, the aspects were aggregated by dimension and their scores were composed using arithmetic mean of their respective aspects. Example: topics EC1 to EC4 were aggregated in economic performance aspect. Finally the overall score gathering the scores of the 3 dimensions is the top level. Exception was made for the social dimension, where there is a category level as suggested by GRI guidelines.

By using arithmetic mean, we say that every information/topic, to compose the score in each aspect and every aspect in each dimension, has the same weight, despite they (the aspects and dimensions) have greater or lesser amount of information/topic. For instance, the 4 topics of aspect Economic performance have the same weight as the 3 topics of aspect Market presence and as the 2 topics of the aspect Indirect economic impacts. And these 3 aspects in the economic dimension have the same importance as the 9 aspects of the environmental dimension. This can be visualized in appendix 1 .

Having the scores calculated, a quantitative approach is employed for statistical analysis. Initially a descriptive 
analysis of the scores by index groups, economic sectors and total of 60 companies were performed.

To verify whether the data sets follow a normal probability distribution, Kolmolgorov-Smirnov and Shapiro-Wilk tests were applied. In the case any data set is not normally distributed, non-parametric statistical tests were applied. Mann-Whitney test was applied for two data sets comparison. When the comparison among three or more data sets was performed, Kruskal-Wallis test was used.

Once statistically significant differences are detected in the Kruskal-Wallis, these differences were investigated by applying post-hoc test suggested by Siegel and Castellan (1988), and Daniel (1978). To study the dependence between two dimensions both Pearson and Spearman correlations were used.

\section{Results and Discussion}

\subsection{Ranking the Companies}

The analysis of the reports resulted in a ranking, which summarizes the quality of disclosure that companies achieved in all the triple bottom line dimensions. The top 20 companies are listed in table 2 . This table exposes the differences in grading of the individual top 20 companies.

Table 2. Top 20 companies

\begin{tabular}{lllll}
\hline Ranking & Company & Sector & Index & Score \\
\hline $1^{\circ}$ & Natura & Ind & ISE & 0,8962 \\
$2^{\circ}$ & Fibria & Ind & ISE & 0,8152 \\
$3^{\circ}$ & ItaúUnibanco & Fin & ISE & 0,8143 \\
$4^{\circ}$ & Coelce & Infra & ISE & 0,8063 \\
$5^{\circ}$ & Energias BR & Infra & ISE & 0,7782 \\
$6^{\circ}$ & Banco do Brasil & Fin & ISE & 0,7705 \\
$7^{\circ}$ & Sona Sierra & Serv & NM & 0,7470 \\
$8^{\circ}$ & Cemig & Infra & ISE & 0,7374 \\
$9^{\circ}$ & Eternit & Ind & NM & 0,7159 \\
$10^{\circ}$ & Sul America & Fin & ISE & 0,7060 \\
$11^{\circ}$ & SuzanoPapel & Ind & ISE & 0,6658 \\
$12^{\circ}$ & BR Foods & Ind & ISE & 0,6643 \\
$13^{\circ}$ & Sabesp & Infra & ISE & 0,6465 \\
$14^{\circ}$ & Cesp & Infra & ISE & 0,6379 \\
$15^{\circ}$ & TIM & Infra & ISE & 0,6295 \\
$16^{\circ}$ & Vale & Ind & ISE & 0,6058 \\
$17^{\circ}$ & Ecorodovias & Serv & ISE & 0,5808 \\
$18^{\circ}$ & Light S/A & Infra & ISE & 0,5729 \\
$19^{\circ}$ & Redecard & Fin & ISE & 0,5588 \\
$20^{\circ}$ & Copel & Infra & ISE & 0,5551 \\
\hline
\end{tabular}

Source: the authors.

ISE companies occupy eighteen of top 20 first positions in the ranking, while the only two NM companies occupy the $7^{\text {th }}$ and $9^{\text {th }}$ positions respectively. Two companies are from the Services sector, four from the Financial sector, six from the Industrial sector and eight from the Infrastructure sector.

Although Natura achieved a very good overall score, this quality scenario is not shared by other top 20 companies. Only $30 \%$ of top 20 achieved a score above 0.75 ; the remaining 14 companies scored between 0.51 and 0.75 . Looking to the whole sample, the quality distribution is as follows: $10 \%$ achieved score above $0.75 ; 27 \%$ between 0.51 and $0.75 ; 30 \%$ between 0.26 and 0.5 and $33 \%$ scored below 0.25 . 
Table 3 shows the quality of disclosure that companies achieved in each of the three dimensions of sustainability. We notice that 11 companies, of the top 20 of table 2, are present in the ranking of top 20 in the social, economic and environmental dimensions. These companies can be seen in bold in Table 3. This might indicate that most companies tend to report at equivalent level of quality and quantity in all the three dimensions of the sustainability. Another interesting aspect is that the highest scores for the Economic and the Environmental dimensions are both higher than the highest score in table 2 ( 0.896 for Natura).

Table 3. Top 20 level of disclosure for each TBL dimension

\begin{tabular}{|c|c|c|c|c|c|c|c|c|}
\hline Company & Sector & Econ. & Company & Sector & Environ. & Company & Sector & Social \\
\hline ItaúUnibanco & Fin & 0,9722 & Natura & Ind & 0,9130 & Fibria & Ind & 0,8406 \\
\hline Natura & Ind & 0,9375 & Cemig & Infra & 0,8602 & Natura & Ind & 0,8382 \\
\hline Sabesp & Infra & 0,9306 & Coelce & Infra & 0,8519 & Sul America & Fin & 0,8065 \\
\hline Fibria & Ind & 0,8681 & Energias BR & Infra & 0,8352 & Banco do Brasil & Fin & 0,8007 \\
\hline Banco do Brasil & Fin & 0,8472 & Sona Sierra & Serv & 0,8324 & Energias BR & Infra & 0,7912 \\
\hline Coelce & Infra & 0,8264 & Eternit & Ind & 0,8296 & Coelce & Infra & 0,7408 \\
\hline Vale & Ind & 0,7917 & CPFL Energia & Infra & 0,7806 & ItaúUnibanco & Fin & 0,7368 \\
\hline Eternit & Ind & 0,7639 & Sul America & Fin & 0,7491 & Light S/A & Infra & 0,7196 \\
\hline Cesp & Infra & 0,7431 & Fibria & Ind & 0,7370 & Sona Sierra & Serv & 0,7071 \\
\hline TIM & Infra & 0,7361 & ItaúUnibanco & Fin & 0,7340 & Cemig & Infra & 0,6993 \\
\hline Energias BR & Infra & 0,7083 & BR Foods & Ind & 0,7296 & SuzanoPapel & Ind & 0,6868 \\
\hline WEG & Ind & 0,7014 & TIM & Infra & 0,6944 & Sabesp & Infra & 0,6728 \\
\hline Sona Sierra & Serv & 0,7014 & Banco do Brasil & Fin & 0,6634 & Cesp & Infra & 0,6446 \\
\hline Copasa & Infra & 0,6736 & Copel & Infra & 0,6509 & Bradesco & Fin & 0,6329 \\
\hline SuzanoPapel & Ind & 0,6736 & SuzanoPapel & Ind & 0,6370 & BR Foods & Ind & 0,6106 \\
\hline Cemig & Infra & 0,6528 & Redecard & Fin & 0,6259 & Copel & Infra & 0,5908 \\
\hline BR Foods & Ind & 0,6528 & Tractabel & Infra & 0,6231 & Eletrobrás & Infra & 0,5760 \\
\hline Embraer & Ind & 0,6181 & Ecorodovias & Serv & 0,6185 & Tractabel & Infra & 0,5714 \\
\hline Cosan & Ind & 0,5764 & Vale & Ind & 0,5370 & IndustriasRomi & Ind & 0,5615 \\
\hline Sul America & Fin & 0,5625 & Light S/A & Infra & 0,5269 & Ecorodovias & Serv & 0,5615 \\
\hline
\end{tabular}

Source: the authors.

\subsection{Quality of Information Analysis Disclosed by Economic Sectors and by Index Group}

Table 4 shows a descriptive statistics of the total sample (60 companies), of each index group (ISE and NM) and of each economic sector. The score of the total sample was of 0.4127. ISE companies have much better score when compared with NM, 0.523 and 0.247 respectively. These results are in line with those in table 2, in which 18 of top 20 companies have the best scores. By economic sector, infrastructure has the highest score $(0.546)$ followed by financial $(0.494)$, industrial $(0.413)$ and services $(0.243)$. Again, the results are similar to top 20 results, in which 8 companies are from Infrastructure, 6 from Industrial, 4 from Financial and 2 from Services.

The next step is to decide the use of parametric or nonparametric statistical approach in our sample. Both Komolgorov-Smirnovand Shapiro-Wilk nonparametric normality tests were applied and table 5 shows the goodness of fit results when all companies are taken together and when they are separated in economic sectors and in index groups.

Using a 0.05 significance level, all the results for total sample, by index group and by economic sector, do not present as a normal probability distribution. This can be seen in the p-value column. When p-value is lower than the significance level assumed for the test the null hypothesis is rejected. So, assuming a conservative approach, the analysis will be performed using nonparametric statistical tests, such as Kuskal-Wallis and Mann-Whitney. 
Table 4. Descriptive summary for the score of the company subsets

\begin{tabular}{lllllll}
\hline Subset & $\mathrm{N}$ & Mean & Std. Deviation & Std. Error & Minimum & Maximum \\
\hline All Companies & 60 & .4127 & .2379 & .0307 & .0167 & .8962 \\
Fin & 9 & .4941 & .2192 & .0731 & .2830 & .8143 \\
Infra & 16 & .5461 & .1687 & .0422 & .2056 & .8063 \\
Ind & 18 & .4132 & .2562 & .0604 & .0687 & .8962 \\
Serv & 17 & .2437 & .1908 & .0463 & .0167 & .7470 \\
ISE & 36 & .5235 & .2025 & .0337 & .1938 & .8962 \\
NM & 24 & .2465 & .1865 & .0381 & .0167 & .7470 \\
\hline
\end{tabular}

Table 5. Normality test

\begin{tabular}{|c|c|c|c|c|c|c|c|}
\hline & \multirow{2}{*}{ Companies subsets } & \multicolumn{3}{|c|}{ Kolmogorov-Smirnov $^{\mathrm{a}}$} & \multicolumn{3}{|c|}{ Shapiro-Wilk } \\
\hline & & Statistic & $\mathrm{df}$ & p-value & Statistic & $\mathrm{df}$ & p-value \\
\hline \multirow[t]{7}{*}{ Score } & All Companies & .102 & 60 & .189 & .951 & 60 & .018 \\
\hline & Financial & .284 & 9 & .035 & .825 & 9 & .039 \\
\hline & Industrial & .196 & 18 & .066 & .925 & 18 & .156 \\
\hline & Infrastructure & .134 & 16 & $.200^{*}$ & .958 & 16 & .625 \\
\hline & Services & .221 & 17 & .026 & .867 & 17 & .020 \\
\hline & ISE & .108 & 36 & $.200^{*}$ & .953 & 36 & .128 \\
\hline & $\mathrm{NM}$ & .170 & 24 & .071 & .857 & 24 & .003 \\
\hline
\end{tabular}

a. Lillie for significance correction

Table 6. Kruskal-Wallis multiple comparison among the four economic sectors

\begin{tabular}{llllll}
\hline & Sector & $\mathrm{N}$ & MeanRank & Test Statistics & \\
\hline Score & Financial & 9 & 37.56 & Chi-Square & 15.400 \\
& Infra & 16 & 40.31 & Df & 3 \\
Industrial & 18 & 30.17 & Asymp. p-value & $\mathbf{. 0 0 2}$ \\
Services & 17 & 17.88 & & \\
& Total & 60 & & & \\
\hline
\end{tabular}

Table 7. Post-hoc test for Kruskal ${ }^{\mathrm{a}}$ among the four economic sectors

\begin{tabular}{llll}
\hline Sector & $\mathrm{N}$ & \multicolumn{2}{l}{ Subset for alpha $=0.05$} \\
\cline { 3 - 3 } & 16 & 1 & 2 \\
\hline Infra & 9 & 40.31 & \\
Fin & 18 & 37.56 & 30.17 \\
Ind & 17 & 30.17 & 17.88 \\
Serv & & & \\
\hline
\end{tabular}

a. Adjustment in the level of significance (Siegel\& Castellan, 1988)

Table 6 shows the multiple comparison Kruskal-Wallis nonparametric test across the four distinct economic sectors. Using 0.05 significance level, this test points that there is significance in the differences observed in the sectors as can be seen in the as Asymp. p-value. 
In order to identify whether there are homogeneous economic sectors, we apply the post-hoc test for Kruskal-Wallis. This test adjusts the level of significance of Kruskal-Wallis for multiple comparisons. The results are displayed in table 7.

So, this table indicates that companies from Infrastructure and Financial sectors present better quality content reported when compared with Service companies. Why does infrastructure sector present better quality reports than service sector? Because the bulk of infrastructure companies of our sample is concentrated in electric energy and natural gas distribution. Possible reasons are their concerns on issues like environment preservation, climate changes, reduction in greenhouse gas emission and conscientious use of energy. These companies' strategy encompasses their relationship with society at large, with its internal public, with suppliers, and consumers, in addition to the responsibility concerning its products, services and respect for human rights. They act according to the legitimacy and stakeholders theories. The information disclosed is important to change society's perception towards them while shaping stakeholders' opinions in a positive way. Unfortunately, this is not likely the scenario for service companies.

These results are similar to those presented by Dias (2009). The quality of disclosure was better for the financial sector followed by industrial and services sectors. He did not include infrastructure sector in his work.

To compare the disclosure quality of ISE and NM index companies, Mann-Whitney test was applied. The results are presented in table 8 . They clearly show that there is significant difference between companies in ISE and companies in NM as can be seen in the Asymp. p-value (compatible with zero). ISE companies display much better general quality content than companies in NM.

The adoption of superior sustainable practices is expected to produce better quality information for such companies. Furthermore, belonging to a sustainability price index puts pressure for a higher level of disclosure. We can say that there is a relation between level of disclosure and the presence of the company in a sustainability price index as Quick (2008) and Rover et al. (2008) suggested in their works. Ameer \& Othman (2012) go beyond by stating that these companies have improved financial performance.

Table 8. Comparison between ISE and NM groups

\begin{tabular}{llllll}
\hline Group & $\mathrm{N}$ & MeanRank & Sum of Ranks & Mann-Whitney Test & \\
\hline ISE & 36 & 38.83 & 1398.00 & Mann-Whitney U & 142.000 \\
NM & 24 & 18.00 & 432.00 & Wilcoxon W & 432.000 \\
Total & 60 & & & Z & -4.527 \\
Asymp. p-value (2-tailed) & & $\mathbf{. 0 0 0}$ & & \\
\hline
\end{tabular}

Table 9. Descriptive summary of the sustainability dimensions

\begin{tabular}{lllllll}
\hline Dimension & $\mathrm{N}$ & Mean & Std. Deviation & Std. Error & Minimum & Maximum \\
\hline Economical & 60 & .4549 & .2447 & .0316 & .0208 & .9722 \\
Environmental & 60 & .3669 & .2869 & .0370 & .0000 & .9130 \\
Social & 60 & .4165 & .2488 & .0321 & .0292 & .8406 \\
\hline
\end{tabular}

Table 10. Normality test for the dimensions

\begin{tabular}{lllllll}
\hline Dimension & \multicolumn{3}{l}{ Kolmogorov-Smirnov } \\
\cline { 2 - 7 } & Statistic & df & p-value & Statistic & Df & p-value \\
\hline Economical & .114 & 60 & .052 & .964 & 60 & .073 \\
Environmental & .150 & 60 & .002 & .908 & 60 & .000 \\
Social & .106 & 60 & .089 & .938 & 60 & .004 \\
\hline
\end{tabular}

a. Lillie for significance correction 


\subsection{Analysis of Quality of Information Disclosed by Three Sustainability Dimensions}

Table 9 shows a descriptive statistics of the total sample (60 companies) in each dimension. The scores of the three dimensions are relatively even. Companies that reported in the economic, environmental and social dimensions scored $0.455,0.367$ and 0.416 respectively.

Table 10 shows the goodness of fit results using 0.05 significance level. All the dimensions results cannot be considered as normally distributed variables. This can be seen in the p-value column. Based on this finding, the nonparametric Kruskal-Wallis comparison test was applied.

This test points that there is no significance in the differences observed in the dimensions for all companies as can be seen in the Asymp. p-value (see table 11). Similar finding has also been informed by Roca \& Searcy (2012) and Perez \& Sanchez (2009), although the latter were more focused on frequency rather than quality. This result confirms what was indicated in table 3 , that most companies tend to report at equivalent level of quality and quantity in all the three dimensions of the sustainability. Eleven companies of the top 20 of table 2 are present in the ranking of top 20 in the social, economic and environmental dimensions. As table 11 shows, the same behavior can be seen when companies from each activity sector are investigated separately. We can conclude that the companies, regardless the sector, are reporting the content in all the three dimensions with same quality level. A good sustainability report is directly related to the good content in all the tree dimensions. This can be confirmed in the Spearman and Pearson tests.

Table 11. Kruskal-Wallis multiple comparisons among dimensions (all companies and by sectors)

\begin{tabular}{|c|c|c|c|c|c|}
\hline & Dimension & $\mathrm{N}$ & MeanRank & Test Statistics & \\
\hline \multirow[t]{4}{*}{ All companies } & Economic & 60 & 99.60 & Chi-Square & 4.123 \\
\hline & Environmental & 60 & 80.37 & Df & 2 \\
\hline & Social & 60 & 91.53 & Asymp. p-value & .127 \\
\hline & Total & 180 & & & \\
\hline \multirow[t]{4}{*}{ Financial } & Economic & 9 & 13.44 & Chi-Square & 1.697 \\
\hline & Environmental & 9 & 11.89 & Df & 2 \\
\hline & Social & 9 & 16.67 & Asymp. p-value & .428 \\
\hline & Total & 27 & & & \\
\hline \multirow[t]{4}{*}{ Infra } & Economic & 16 & 24.44 & Chi-Square & .071 \\
\hline & Environmental & 16 & 23.88 & Df & 2 \\
\hline & Social & 16 & 25.19 & Asymp. p-value & .965 \\
\hline & Total & 48 & & & \\
\hline \multirow[t]{4}{*}{ Industrial } & Economic & 18 & 33.28 & Chi-Square & 3.649 \\
\hline & Environmental & 18 & 24.39 & Df & 2 \\
\hline & Social & 18 & 24.83 & Asymp. p-value & .161 \\
\hline & Total & 54 & & & \\
\hline \multirow[t]{4}{*}{ Services } & Economic & 17 & 30.26 & Chi-Square & 3.845 \\
\hline & Environmental & 17 & 20.50 & Df & 2 \\
\hline & Social & 17 & 27.24 & Asymp. p-value & .146 \\
\hline & Total & 51 & & & \\
\hline
\end{tabular}

Significant correlation (parametric Pearson correlation and nonparametric Spearman correlation) among the three dimensions, showed in table 12, corroborates with the Kruskal-Wallis results. The Pearson parametric correlation can be applied in this case assuming a linear relation among the three dimensions. As we can see in table 12 , both parametric and nonparametric correlations have strong statistical significance $(* *$ correlation is significant at the 0.01 level). 
Table 12. Parametric and nonparametric correlations among the sustainability report dimensions

\begin{tabular}{|c|c|c|c|c|c|}
\hline Correlations & & & Economic & Environ. & Social \\
\hline Pearson Correlation & Economic & CorrelationCoefficient & 1 & $.718^{* *}$ & $.749^{* *}$ \\
\hline \multirow[t]{5}{*}{$\mathrm{N}=60$} & & Sig. (2-tailed) & & .000 & .000 \\
\hline & Environment & CorrelationCoefficient & $.718^{* *}$ & 1 & $.794^{* *}$ \\
\hline & & Sig. (2-tailed) & .000 & & .000 \\
\hline & Social & CorrelationCoefficient & $.749^{* *}$ & $.794^{* *}$ & 1 \\
\hline & & Sig. (2-tailed) & .000 & .000 & \\
\hline Spearman'srho & Economic & CorrelationCoefficient & 1.000 & $.694^{* *}$ & $.743^{* *}$ \\
\hline \multirow[t]{5}{*}{$\mathrm{N}=60$} & & Sig. (2-tailed) & . & .000 & .000 \\
\hline & Environmental & CorrelationCoefficient & $.694^{* *}$ & 1.000 & $.783^{* *}$ \\
\hline & & Sig. (2-tailed) & .000 & . & .000 \\
\hline & Social & CorrelationCoefficient & $.743 * *$ & $.783 * *$ & 1.000 \\
\hline & & Sig. (2-tailed) & .000 & .000 & . \\
\hline
\end{tabular}

** Correlation is significant at the 0.01 level (2-tailed).

Similar results were obtained when dimensions were compared in each of the index groups (ISE and NM). Table 13 shows that no difference among the three dimensions could by observed in ISE group. For NM group Kruskal-Wallis comparison detected a significant difference among economic, environmental and social dimensions (p-value lower than 0.05). The post-hoc test for Kruskal-Wallis was applied to identify these differences. Table 14 points that, for NM companies, the sustainability report is better for economic dimension than for environmental. This result might reflect the lower complexity to deal with the nine economic indicators as compared to the other two dimensions.

Table 13.Kruskal-Wallis multiple comparisons among dimensions (by groups)

\begin{tabular}{llllll}
\hline & Dimension & $\mathrm{N}$ & Mean Rank & Test Statistics & \\
\hline ISE & Economic & 36 & 56.53 & Chi-Square & .918 \\
& Environmental & 36 & 50.42 & Df & 2 \\
Social & 36 & 56.56 & Asymp. p-value & .632 \\
Total & 108 & & & \\
NM & Economic & 24 & 45.71 & Chi-Square & 8.429 \\
& Environmental & 24 & 28.25 & df & 2 \\
& Social & 24 & 35.54 & Asymp. p-value & $\mathbf{. 0 1 5}$ \\
& Total & 72 & & & \\
\hline
\end{tabular}

Table 14. Post-hoc test for Kruskal among the three dimensions for NM

\begin{tabular}{llllll}
\hline \multirow{2}{*}{ Sector } & & & & \multicolumn{2}{l}{ Subset for alpha $=0.05$} \\
\cline { 5 - 5 } NM & & $\mathrm{N}$ & Mean Rank & 1 & 2 \\
& Economic & 24 & 45,71 & 45,71 & 35,54 \\
& Social & 24 & 35,54 & 35,54 & 28,25 \\
& Environmental & 24 & 28,25 & & \\
& Total & 72 & & & \\
\hline
\end{tabular}

a. Adjustment in the level of significance (Siegel. 1988) 
Besides economic sectors and index group analysis, we also analyzed whether there are significant differences: 1) in the economic, environmental and social dimensions between ISE and NM (control companies); 2) in the economic, environmental and social dimensions across the four economic sectors.

We found significant differences in the quality of the sustainability reports in the two index groups. ISE companies present better reports in all dimensions than NM (control) companies for all the three dimensions. See table 15. Therefore, H1, H2 and H3 hypotheses are accepted, i.e., information disclosed of the economic, social and environmental dimension in 2011 of ISE companies is better than in the control companies.

When Kruskal-Wallis test is applied in the three dimensions, separated by the four economic sectors, similar results appear for all dimensions. In all dimensions, significant differences were found. The quality of the sustainability report seems to be better for companies that belong to the infrastructure sector, when compared to service sector. For social dimension, companies from Industrial sector have also better reports than that from services. Homogeneous subsets are present in table 16 and follow the similar pattern presented in table 7.

Therefore, the hypothesis $\mathrm{H} 4$ is rejected, i.e., there are differences in the quality of sustainability report among distinct activity sectors. In general, reports from infrastructure sector are better than from service sector. This behavior could be noted not only in the general quality but also when each dimension is analyzed separated.

However, regardless the economic sectors involved, respondents in Okoye et al. study (2013) perceived that managing social and environmental stakeholder needs is crucial in sustaining a long term relationship with the management. Again, the companies are acting according to the legitimacy and stakeholders theories.

\section{Conclusion}

This paper tests two types of hypotheses: the hypothesis that companies with superior sustainability practices (ISE) have superior quality information in all sustainability dimensions (economic, environmental and social) than those companies which place emphasis on superior corporate governance practices (NM), identified as control sample; and the hypothesis that there is no difference in the quality of the sustainability information among different economic sectors. We examined the sustainability reports of sixty companies and based on content analysis, developed a scoring system (from 0 to 1 ) reflecting the quality of information reported.

Our findings show that sustainable companies (ISE) occupy eighteen of top 20 first positions in the ranking.

Nevertheless, the quality information of the whole sample is not meaningful, i.e., $37 \%$ of the companies achieved score above $0.5 ; 30 \%$ between 0.26 and 0.5 and $33 \%$ scored below 0.25 . The best company scored 0.896 and the worst of the 60 companies scored 0.0167 .

Table 15. Comparison between ISE and NM groups, separated by dimensions

\begin{tabular}{lllllll}
\hline & Group & $\mathrm{N}$ & MeanRank & Sum of Ranks & Mann-Whitney Test \\
\hline Economic & ISE & 36 & 37,54 & 1351,50 & Mann-Whitney U & 178,500 \\
& NM & 24 & 19,94 & 478,50 & Wilcoxon W & 478,500 \\
& Total & 60 & & Z & Asymp. p-value (2-tailed) & $-3,826$ \\
& & & & & Mann-Whitney U & 163,500 \\
Environmental & ISE & 36 & 37,96 & 1366,50 & Wilcoxon W & 463,500 \\
& NM & 24 & 19,31 & 463,50 & Z & $-4,052$ \\
& Total & 60 & & & Asymp. p-value (2-tailed) & $\mathbf{0 0 0}$ \\
Social & & & & Mann-Whitney U & 124,500 \\
& ISE & 36 & 39,04 & 1405,50 & Wilcoxon W & 424,500 \\
& NM & 24 & 17,69 & 424,50 & Z & $-4,640$ \\
\hline
\end{tabular}


Table 16. Post-hoc test for Kruskal ${ }^{\mathrm{a}}$ among the four sectors separated by dimensions

\begin{tabular}{|c|c|c|c|c|c|}
\hline \multirow[b]{2}{*}{ Sector } & & \multirow[b]{2}{*}{$\mathrm{N}$} & \multirow[b]{2}{*}{ MeanRank } & \multicolumn{2}{|c|}{ Subset for alpha $=0.05$} \\
\hline & & & & 1 & 2 \\
\hline \multirow[t]{5}{*}{ Economic } & Financial & 9 & 31,83 & 31,83 & \\
\hline & Infra & 16 & 38,94 & 38,94 & 38,94 \\
\hline & Industrial & 18 & 33,56 & 33,56 & 33,56 \\
\hline & Services & 17 & 18,62 & & 18,62 \\
\hline & Total & 60 & & & \\
\hline \multirow[t]{5}{*}{ Environmental } & Financial & 9 & 34,56 & 34,56 & \\
\hline & Infra & 16 & 40,16 & 40,16 & 40,16 \\
\hline & Industrial & 18 & 30,72 & 30,72 & 30,72 \\
\hline & Services & 17 & 19,03 & & 19,03 \\
\hline & Total & 60 & & & \\
\hline \multirow[t]{5}{*}{ Social } & Financial & 9 & 41,67 & 41,67 & \\
\hline & Infra & 16 & 40,19 & 40,19 & \\
\hline & Industrial & 18 & 27,19 & 27,19 & 27,19 \\
\hline & Services & 17 & 18,97 & & 18,97 \\
\hline & Total & 60 & & & \\
\hline
\end{tabular}

a. Adjustment in the level of significance (Siegel \& Castellan, 1988)

Overall our statistical results confirm that ISE companies tend to disclose more information and in a more adequate way than NM, and in general, the companies are reporting the content in all the three dimensions with same quality level. A good sustainability report is directly related to the good content in all the tree dimensions. Furthermore, companies from Infrastructure sector present better quality content reported when compared to Service companies.

Sustainability reports still have a big room for improvement, which echoes within the literature analyzed. ISE companies should have better disclosure levels, as it is expected of them because they represent the best sustainability practices in the market. NM companies that produced sustainability report should be in bigger proportion of total NM index group. Hopefully, the information on sustainability practices that the firm develops and discloses should facilitate the development of a better corporate government, notably of better internal controls systems and decision making, and thus, increase the number of NM companies that report sustainability practices and actions. Companies need to disclose their information in a more integrated way, addressing sustainability issues under the scope of business strategy.

One issue we did not address in our paper is the evolution of the quality of the sustainability reports in a longitudinal perspective. We address the quality issue in a transversal perspective, reports of year 2011, and this is the major limitation of our study. This can be the research question for a future work, is there proven evidences on the evolution of the quality of the sustainability reports in a longitudinal perspective? We suggest that future research should endeavor to ascertain this evolution in a longer period.

\section{References}

Aktas, R., Kayalidere, K., \& Kargin, M. (2013). Corporate Sustainability Reporting and Analysis of Sustainability Reports in Turkey. International Journal of Economics and Finance, 5(3). http://dx.doi.org/10.5539/ijef.v5n3p113

Ameer. R., \& Othman. R. (2012). Sustainability practices and corporate financial performance: a study based on the top global corporations. Journal of Business Ethics, 108, 61-79. http://dx.doi.org/10.1007/s10551-011-1063-y

Caron, M. A., \& Turcotte, M. F. B. (2009). Path Dependence and Path Creation: framing the extra-financial information market for a sustainable trajectory. Accounting, Auditing \& Accountability Journal, 22(2), 


\section{2-297. http://dx.doi.org/10.1108/09513570910933979}

Carvalho, F. M., \& Siqueira, J. R. M. (2007). Análise da Utilização dos Indicadores essenciais da GRI nos Relatórios Sociais de Empresas Latino-Americanas. Pensar Contábil, 9(38).

Coalition for Environmentally Responsible Economy (CERES). (2010). The 21st century corporation: The Ceres Roadmap for Sustainability.

Cho, C. H., \& Patten, D. M. (2007). The role of environmental disclosures as tools of legitimacy: A research note. Accounting, Organization and Society, 32(7-8), 639-647. http://dx.doi.org/10.1016/j.aos.2006.09.009

Daniel, W. W. (1978). Applied Nonparametric Statistics. Boston: Houghton Mifflin Company.

Davys, C., \& Searcy, C. (2010). A review of Canadian Corporate Sustainable Development Reports. Journal of Global Responsibility, 1(2), 316-329. http://dx.doi.org/10.1108/20412561011079425

Deegan, C. (2002). The legitimizing effect of social and environmental disclosures - a theoretical foundation. Accounting, Auditing \& Accountability Journal, 15(3), 282-311. http://dx.doi.org/10.1108/09513570210435852

Dias, A. (2009). O Relato da Sustentabilidade Empresarial: Evidência empírica nas empresas cotadas em Portugal. Portuguese Journal of Accounting \& Management, 8, 111-150.

Economist Intelligence Unit (EIU). (2008). Doing good: Business and the sustainability challenge.

Freeman, R. E., Wicks, A. C., \& Parmar, B. (2004). Stakeholder Theory and The Corporate Objective Revisited. Organization Science, 15(3), 364-369. http://dx.doi.org/10.1287/orsc.1040.0066

Gray, R. B., Kouhy, R., \& Lavers, S. (1996). Corporate Social and Environmental Reporting: A Review of the Literature and a Longitudinal Study of UK Disclosure. Accounting, Auditing \& Accountability Journal, 8(2), 47-77. http://dx.doi.org/10.1108/09513579510146996

Guthrie, J., \& Abeysekera, I. (2006). Content analysis of social environmental reporting: What is new? Journal of Human Resource Costing \& Accounting, 10(2), 114-126. http://dx.doi.org/10.1108/14013380610703120

Hart, S. L., \& Milstein, M. B. (2004). Criando Valor Sustentável. RAE Executivo, 3(2).

Hedberg, C. J., \& Von Malmborg, F. (2003). The global reporting initiative and corporate sustainability reporting in Swedish companies. Corporate Social Responsibility and Environmental Management, 10, 153-164. http://dx.doi.org/10.1002/csr.38

Hubbard, G. (2011). The Quality of the Sustainability Reports of Large International Companies: An Analysis. International Journal of Management, 28(3).

International Network for Environmental Management (INEM). (2001). The INEM Sustainability Reporting Guide. $\quad$ Retrieved September $3 \mathrm{rd}, \quad 2012, \quad$ from http://www2.accaglobal.com/pdfs/environment/newsletter/sustainability_reporting.pdf

Isarksson, R., \& Steimle, U. (2009). What does GRI reporting tell us about corporate sustainability? The TQM Journal, 21(2), 168-181. http://dx.doi.org/10.1108/17542730910938155

KPMG. (2011a). Survey of Corporate Responsibility Reporting. Retrieved September 3rd, 2012, from http://www.kpmg.com/PT/pt/IssuesAndInsights/Documents/corporate-responsibility2011.pdf

KPMG. (2011b). Corporate Sustainability: A Progress Report. Retrieved September 3rd, 2012, from http://www.kpmg.com/Global/en/IssuesAndInsights/ArticlesPublications/Documents/corporate-sustainabilit $\mathrm{y}-\mathrm{v} 2 . \mathrm{pdf}$

Konar, S., \& Cohen, M. A. (2001). Does the market value environmental performance? The Review of Economics and Statistics, 83(2), 281-289. http://dx.doi.org/10.1162/00346530151143815

Lo, S., \& Sheu, H. (2007). Is Corporate Sustainability a Value-Increasing Strategy for Business? Journal compilation, 15(2). Blackwell Publishing Ltd.

López, M. V., Garcia, A., \& Rodriguez, L. (2007). Sustainable Development and Corporate Performance: A Study Based on the Dow Jones Sustainability Index. Journal of Business Ethics, 75, 285-300. http://dx.doi.org/10.1007/s10551-006-9253-8

Morhardt, J. E., Baird, S., \& Freeman, K. (2002). Scoring Corporate Environmental and Sustainability Reports Using GRI 2000, ISO 14031 and othercriteria. Corporate Social Environmental Management, 9, 215-233.

Ness, K. E., \& Mirza, A. M. (1991). Corporate social disclosure: A note on a test of agency theory. The British 
Accounting Review, 23(3), 211-217. http://dx.doi.org/10.1016/0890-8389(91)90081-C

Okoye, P. V. C., Egbunike, F. C., \& Meduoye, O. M. (2013). Sustainability Reporting: a paradigm for stakeholder conflict management. International Business Research, 6(5), 157-167.

O'Donovan, G. (2002). Environmental disclosures in the annual report: Extending the applicability and predictive power of legitimacy theory. Accounting, Auditing \& Accountability Journal, 15(3), 344-371. http://dx.doi.org/10.1108/09513570210435870

Perez, F., \& Sanchez, L. E. (2009). Assessing the Evolution of Sustainability Reporting in the Mining Sector. Environmental Management, 43, 949-961. http://dx.doi.org/10.1007/s00267-008-9269-1

Perrini, F., \& Tencati, A. (2006). Sustainability and Stakeholder Management: the Need for New Corporate Performance Evaluation and Reporting Systems. Business Strategy and the Environment, 15, 296-308. http://dx.doi.org/10.1002/bse.538

Quick, R. (2008). Voluntary sustainability reporting practices in Germany: a study on reporting quality. Contabilidade e Gestão, 5, 7-35.

Roca, L. C., \& Searcy, C. (2012). An Analysis of indicators disclosed in corporate sustainability reports. Journal of Cleaner Production, 20, 103-118. http://dx.doi.org/10.1016/j.jclepro.2011.08.002

Ross, S. A. (1973). The Economic Theory of Agency: The Principal's Problem. The American Economic Review, 63(2), 134-139.

Rover, S., Murcia, F. Dal-Ri., Borba, J. Al., \& Vicente, E. F. R. (2008). Divulgação de Informações Ambientais nas Demonstrações Contábeis: Um Estudo Exploratório sobre o Disclosure das Empresas Brasileiras pertencentes a setores de alto impacto ambiental. RCO Revista de Contabilidade e Organizações, 3(2), $53-72$.

Schönbohm, A., \& Hofmann, U. (2012). Comprehensive Sustainability Reporting-A long road to go for German TecDax 30 companies. Berlin School of Economics and Law.

Siegel, S., \& Castellan, N. J. (1988). Nonparametric Statistics for the Behavioral Sciences (2nd ed.). New York: McGraw-Hill.

Singh, R. K., Murty, H. R., Gupta, S. K., \& Dikshit, A. K. (2009). An overview of sustainability assessment methodologies. Ecological Indicators, 9, 189-212. http://dx.doi.org/10.1016/j.ecolind.2008.05.011

Sridhar, K. (2012). The Relationship between the Adoption of Triple Bottom Line and Enhanced Corporate Reputation and Legitimacy. Corporate Reputation Review, 15, 69-87. http://dx.doi.org/10.1057/crr.2012.4

United Nations Environment Programme (UNEP). (2002). Trust Us: The Global Reporters 2002 Survey of Corporate Sustainability Reporting. Retrieved August 23rd, 2012, from http://www.sustainability.com/library/trust-us

United Nations Environment Programme (UNEP). (2006). Tomorrow's value: the global reporters 2006 Survey of corporate Sustainability Reporting. Retrieved August 23rd, 2012, from http://www.sustainability.com/library/global-reporters-methodology\#.UFHmStWe61k 
Appendix 1.

\begin{tabular}{|c|c|c|c|c|c|c|}
\hline \multicolumn{2}{|c|}{ Economic dimension } & \multicolumn{2}{|c|}{ Environmental dimension } & \multicolumn{3}{|l|}{ Social dimension } \\
\hline Aspects & Indicators & Aspects & Indicators & Category & Aspects & Indicators \\
\hline Economic & $(\mathrm{EC} 1+\ldots \mathrm{EC} 4) / 4$ & Material M & $(\mathrm{EN} 1+\mathrm{EN} 2) / 2$ & Labor practices LP & employment $\mathrm{E}$ & $(\mathrm{L} A 1+. \mathrm{LA} 3) / 3$ \\
\hline performance EP & & Energy E & $(\mathrm{EN} 3+\ldots \mathrm{EN} 7) / 5$ & & Labor relation $\mathrm{LR}$ & $(\mathrm{LA} 4+\mathrm{LA} 5) / 2$ \\
\hline Market & $(\mathrm{ED} 5+\ldots \mathrm{EC} 7) / 3$ & Water W & $(\mathrm{EN} 8+\ldots \mathrm{EN} 10) / 3$ & & Occupational OH & $(\mathrm{LA} 6+. \mathrm{LA} 9) / 4$ \\
\hline presence MP & & Biodiversity B & $($ EN11+..EN15)/5 & & Training TE & $(\mathrm{LA} 10+. \mathrm{LA} 12) / 3$ \\
\hline Indirect & $(E C \&+E C 9) / 2$ & Emissions $\mathrm{E}$ & $(\mathrm{EN} 16 \ldots+\mathrm{EN} 25) / 10$ & & Diversity D & $(\mathrm{LA} 13+\mathrm{LA} 14) / 2$ \\
\hline impacts II & & Products P & $(\mathrm{EN} 26+\mathrm{EN} 27) / 2$ & Total LP & $(\mathrm{E}+\mathrm{LR}+\mathrm{OH}+\mathrm{TE}+\mathrm{D}) / 5$ & \\
\hline Total economic & $(\mathrm{EP}+\mathrm{MP}+\mathrm{II}) / 3$ & Compliance $\mathrm{C} 1$ & (EN28) & Human Right HR & investments IP & $(\mathrm{HR} 1+\ldots \mathrm{HR} 3) / 3$ \\
\hline \multirow[t]{20}{*}{ dimension TED } & & Transport T & (EN29) & & non discrimination $\mathrm{N}$ & (HR4) \\
\hline & & Overall 0 & (EN30) & & free association FA & (HR5) \\
\hline & & & & & child labor $\mathrm{CL}$ & (HR6) \\
\hline & & Total environ/ & $(\mathrm{M}+\mathrm{E}+\mathrm{W}+\mathrm{B}+\mathrm{E}+\mathrm{P}+$ & & forced labor FL & (HR7) \\
\hline & & dimension TEM & $\mathrm{C} 1+\mathrm{T}+0) / 9$ & & security SP & (HR8) \\
\hline & & & & & indigenous right $\mathbb{R}$ & (HR9) \\
\hline & & & & Total HR & $(\mathrm{IP}+\mathrm{N}+\mathrm{FA}+\mathrm{CL}+\mathrm{FL}+\mathrm{SP}+\mathrm{IR}) / 7$ & \\
\hline & & & & Social & community C & (SO1) \\
\hline & & & & Performance SP & corruption $\mathrm{CP}$ & $(\mathrm{SO} 2+. . \mathrm{SO} 4) / 3$ \\
\hline & & & & & public policy PP & $(\mathrm{SO} 5+\mathrm{SO}) / 2$ \\
\hline & & & & & anti competitive $\mathrm{AC}$ & $(\mathrm{SO} 7)$ \\
\hline & & & & & compliance $\mathrm{C} 2$ & (SO9) \\
\hline & & & & Total SP & $(\mathrm{C}+\mathrm{CP}+\mathrm{PP}+\mathrm{AC}+\mathrm{C} 2) / 5$ & \\
\hline & & & & Product & customer health $\mathrm{CH}$ & $(\mathrm{PR} 1+\mathrm{PR} 2) / 2$ \\
\hline & & & & responsibility $P R$ & product labelling PL & $(\mathrm{PR} 3+. \mathrm{PR} 5) / 3$ \\
\hline & & & & & mktg communic/MC & $(\mathrm{PR} 6+\mathrm{PR} 7) / 2$ \\
\hline & & & & & customer privacy $\mathrm{CP}$ & (PR\&) \\
\hline & & & & & compliance $\mathrm{C} 3$ & (PR9) \\
\hline & & & & total social & $(\mathrm{CH}+\mathrm{PL}+\mathrm{MC}+\mathrm{CP}+\mathrm{C} 3) / 5$ & \\
\hline & & & & dimension TSO & & \\
\hline Overall score & $(\mathrm{TED}+\mathrm{TEM}+\mathrm{TSO} \mathrm{s}) / 3$ & & & & & \\
\hline
\end{tabular}

\section{Copyrights}

Copyright for this article is retained by the author(s), with first publication rights granted to the journal.

This is an open-access article distributed under the terms and conditions of the Creative Commons Attribution license (http://creativecommons.org/licenses/by/3.0/). 